\title{
Contents, Vol. 48, 1988
}

\section{Editor-in-Chief}

S.M. McCann, Dallas, Tex.

\section{Associate Editors}

C.P. Fawcett, Dallas, Tex. L. Krulich, Dallas, Tex. J.C. Porter, Dallas, Tex.

\section{Editorial Board}

J. Antunes-Rodrigues, Ribeirao Preto

N. Ben-Jonathan, Indianapolis, Ind.

J.E. Blalock, Birmingham, Ala.

D. Cardinali, Buenos Aires

G.V. Childs, Galveston, Tex.

M.J. Cronin, South San Francisco, Calif.

W.F. Crowley, Boston, Mass.

K. Döhler, Wedemark, FRG

H.H. Feder, Newark, N.J.

M. Ferin, New York, N.Y.

J.W. Funder, Melbourne

H. Gainer, Bethesda, Md.

R.R. Gala, Detroit, Mich.

R.V. Gallo, Storrs, Conn.

PC. Goldsmith, San Francisco, Calif.

GA. Gudelsky, Cleveland, Ohio

S.P Kalra, Gainesville, Fla.

Y. Kato, Izumo

F. Kimura, Yokohama

S.W.J. Lamberts, Rotterdam

D. Lincoln, Edinburgh

PJ. Lowry, Reading

R.M. MacLeod, Charlottesville, Va.

GB. Makara, Budapest

F. Mena, Mexico City

K.E. Moore, East Lansing, Mich.

C. Oliver, Marseille

C. Rivier, San Diego, Calif.

J.L. Roberts, New York, N.Y.

D.K. Sarkar, La Jolla, Calif.

P. Smelik, Amsterdam

S.L. Wardlaw, New York, N.Y. 
DBffI 
S. Karger $\cdot$ Medical and Scientific Publishers $\cdot$ Basel $\cdot$ München $\cdot$ Paris $\cdot$ London $\cdot$ New York $\cdot$ New Delhi $\cdot$ Singapore $\mathbf{m}$ Tokyo $\cdot$ Sydney

Drug Dosage

The authors and the publisher have exerted every effort to ensure that drug selection and dosage set forth in this text are in accord with current recommendations and practice at the time of publication. However, in view of ongoing research, changes in government regulations, and the constant flow of information relating to drug therapy and drug reactions, the reader is urged to check the package insert for each drug for any change in indications and dosage and for added warnings and precautions. This is particularly important when the recommended agent is a new and/or infrequently employed drug. 
All rights reserved.

No part of this publication may be translated into other languages, reproduced or utilized in any form or by any means, electronic or mechanical, including photocopying, recording, microcopying, or by any information storage and retrieval system, without permission in writing from the publisher or, in the case of photocopying, direct payment of a specified fee to the Copyright Clearance Center (see 'Information for Readers and Subscribers').

(C) Copyright 1988 by S. Karger AG, P.O! Box, CH-4009 Basel (Switzerland) Printed in Switzerland by Genossenschaftsdruckerei Zürich (gdz) 


\section{Contents Vol. 48,1988}

\section{No.1}

\section{Original Paper}

Possible Involvement of the Hypothalamic Dopaminergic Sys tem in the Prolactin-Inhibitory Effects of the Pinal Gland in Blind-Anosmic Male Rats Leadem, C.A.; Bums, D.M.; Benson, B. 1 Innervation of the Sheep Adrenal Cortex: An Immunohisto-chemical Study with Rat Corticotrophin-Releasing Factor Antiserum Rundle, S.E.; Canny, B.J.; Robinson, P.M.; Funder, J.W. 8

Opioid-Noradrenergic Interactions in the Neurohypophysis. I. Differential Opioid Receptor Regulation of Oxytocin, Vasopressin, and Noradrenaline Release

Zhao, B.; Chapman, C; Bicknell, R J

Opioid-Noradrenergic Interactions in the Neurohypophysis.

II. Does Noradrenaline Mediate the Actions of Endoge nous Opioids on Oxytocin and Vasopressin Release?

Zhao, B.; Chapman, C; Brown, D.; Bicknell, R.J .....

Effects of Intravenous Corticotropin-Releasing Hormone upon Sleep-Related Growth Hormone Surge and Sleep EEG in Man

Holsboer, F.; von Bardeleben, U.; Steiger, A.

Axons Containing a Prolactin-Like Peptide Project into the Perivascular Layer of the Median Eminence: An Immuno-cytochemical Light and Electron Microscope Study in Adult and Infant Rats

Alonso, G.; Siaud, P.; Faivre-Sarrailh, C; Grouselle, D.;

Barbanel, G.; Assenmacher, 1 .

Transplanted Gonadotropin-Releasing Hormone Neurons Promote Pulsatile Luteinizing Hormone Secretion in Congenitally Hypogonadal (hpg) Male Mice

Kokoris, G.J.; Lam, N.Y.; Ferin, M.; Silverman, A.-J.;

Gibson, M.J.

Effects of Ovariectomy and Estradiol Replacement on the

Bindings of ${ }^{125} \mathrm{I}$-Neurotensin in Rat Suprachiasmatic $\mathrm{Nu}$

cleus

Moyse, E.; Miller, M.M.; Rostène, W.; Beaudet, A

Alpha-Adrenergic Control of Serotonin Release from Rat Pi

neal Glands

Aloyo, V.J.; Walker, R.F

Subfornical Organ Connections with Septal Neurons Project

ing to the Median Eminence

Donevan, S.D.; Ferguson, A.V

Delayed Sexual Maturation Induced by Daily Melatonin Administration Eliminates the LH Response to Naloxone despite Normal Responsiveness to GnRH in Juvenile Male Rats

Aubert, M.L.; Rivest, R.W.; Lang, U.; Winiger, B.P.; Sizo-

nenko, P.C

Feedback Regulation of Pulsatile LH Secretion in the Ewe:

Stimulation of Frequency by Estradiol

Kaynard, A.H.; Follett, B.K.; Karsch, F.J 
Autoradiographic Characterization of Binding Sites Labelled with Vasopressin in the Brain of a Urodele Amphibian

Tripp, S.K.; Moore, F.L

Effects of Suckling on the in vivo Release of Thyrotropin-

Releasing Hormone, Dopamine and Adrenaline in the Lac-

tating Rat

Rondeel, J.M.M.; de Greef, W.J.; Visser, T.J.; Voogt, J.L. 93 Chronic Morphine and Testosterone Treatment. Effects on

Sexual Behavior and Dopamine Metabolism in Male

Rats

Clark, J.T.; Gabriel, S.M.; Simpkins, J.W.; Kalra, S.P.;

Kalra, P.S 97

No. 2

\section{Original Paper}

Regulation of the Central Nervous System-Pituitary-Adrenal Axis in Rats after Neonatal Treatment with Monosodium Glutamate Magariños, A.M.; Estivariz, F.;Morado, M.I.;De Nicola, A.F. 105

Positive Feedback in Hypogonadal Female Mice with Preoptic

Area Brain Transplants

Gibson, M.J.; Kokoris, G.J.; Silverman, A.-J.

Estrogen-Dependent and Estrogen-Independent Effects of Pro gesterone on the Electrophysiological Excitability of Dorsal

Midbrain Neurons in Golden Hamsters

Havens, M.D.; Rose, J.D

Localized Increase of GABA Levels in Brain Areas of the Rat and Inhibition of the Plasma LH Rise following Orchidectomy

Donoso, A.0

Changes in the Number of GnRH-Receptive Cells during the

Rat Estrous Cycle: Biphasic Effects of Estradiol

Lloyd, J.M.; Childs, GV.

Sustained Intermittent Release of Gonadotropin-Releasing

Hormone in the Prepubertal Male Rhesus Monkey In

duced by N-Methyl-Z ZL-Aspartic Acid

Gay, V.L.; Plant, T.M

Role of the Hypothalamic TRH in the Regulation of Its Own

Receptors in Rat Anterior Pituitaries

Mori, M.; Yamada, M.; Kobayashi, S

$\begin{array}{llcc}\text { Recombinant } & & \text { Tumor } & \text { Necrosis } \\ \text { ACTH } & \text { Release } & \text { from } & \text { Rat }\end{array}$

in a Prostaglandin

Kehrer, P.; Turnill,

Turnill, D.;

Anterio

Beta

and

Factor

lard, R.C

D.; Dayer,

cAMP 160

J.-M.;

$\begin{array}{ll}\text { Alpha } & \text { but } \\ \text { Cells } & \text { in } \\ \text { Independent } & \end{array}$

vitro

Histaminergic Regulation of Prolactin Secretion: Involvement

of Tuberoinfundibular Dopaminergic Neurons

Knigge, U.; Matzen, S.; Warberg, J 
Prolactin Release Induced by Opiate Agonists, Effect of Glu-cocorticoid Pretreatment in Intact and Adrenalectomized Rats Kiem, D.T.; Kanyicska, B.; Stark, E.; Fekete, M.I.K. ... 174

Specificity of Vasopressin Binding to the Posterior Pituitary

Gland in the Rat. An Autoradiographic Study

Dashwood, M.R.; Robinson, I.C.A.F

Involvement of Dl Dopamine Receptors in the NicotineInduced Neuro-Endocrine Effects and Depletion of Diencephalic Catecholamine Stores in the Male Rat

Andersson, K.; Fuxe, K.; Eneroth, P.; Härfstrand, A.;

Agnati, L.F

\section{Rapid Communications}

The Melatonin Receptors in Rat Ontogenesis

Vanècek, $\mathrm{J}$

Inhibitory Action of Exogenous Oxytocin on Plasma Cortisol

in Normal Human Subjects: Evidence of Action at the

Adrenal Level

Legros, J.-J.; Chiodera, P.; Geenen, V

Localization of Neuropeptide Y Binding Sites in the Zona

glomerulosa of the Bovine Adrenal Gland

Torda, T.; Cruciani, R.A.; Saavedra, J.M..

Tissue-Specific Regulation of Pyroglutamate Aminopeptidase

II Activity by Thyroid Hormones

Ponce, G; Charli, J.-L.; Pasten, J.A.; Aceves, C; Joseph-

Bravo, P.

Immunoneutralization of Oxytocin Attenuates Preovulatory

Prolactin Secretion during Proestrus in the Rat

Sarkar, D.K

No. 3

\section{Original Paper}

Relation of Endogenous Systemic and Brain Angiotensin II, Arginine, Vasopressin and Prolactin with the Genesis of Salt Appetite in Cattle

Bell, F.R.; Doris, P.A.; Simmonds, A

Differential Angiotensin-Converting Enzyme Inhibition in Brain after Oral Administration of Perindopril Demonstrated by Quantitative in vitro Autoradiography (With 1 color plate)

Sakaguchi, K.; Chai, S.-Y.; Jackson, B.; Johnston, C.I.;

Mendelsohn, F.A.0 .

Stimulatory Effect of Isoproterenol but Not of Dibutyryl Cyclic AMP on N-Acetyltransferase Activity and Melatonin Content of Syrian Hamster Pineal Gland in Organ Culture

Santana, C; Guerrero, J.M.; Reiter R.J.; Puig-Domingo,

M.; Gonzalez-Brito, A.

Corticosterone Decreases 3/4-Glutamate Binding in Rat Hip-

pocampal Formation

Halpain, S.; McEwen, B.S

Opposite Changes of Pituitary and Ovarian Receptors for

LHRH in Ageing Rats: Further Evidence for a Direct Neu

ral Control of Ovarian LHRH Receptor Activity

Marchetti, B.; Cioni, M 
Effect and Site of Action of Hypothalamic Neuropeptides on Prolactin Release in Sheep Thomas, G.B.; Cummins, J.T.; Griffin, N; Clarke, I.J. 252

Effects of Systemic and Intracerebroventricular Cysteamine on Dexamethasone-Induced Suppression of Corticosterone

Levels in the Rat

Radke, J.M.; Vincent, S.R 258

Reproductive Refractoriness of the Ewe to Inhibitory Photo-period Is Not Caused by Alteration of the Circadian Secretion of Melatonin Malpaux, B.; Moenter, S.M.; Wayne, N.L.; Woodfill, C.J.I.;

Karsch, F.J

Localization of Cerebral Protein Synthesis Alterations in Re sponse to Water Deprivation in Rats

Lepetit, P.; Lestage, P.; Jouvet, M.; Bobillier, P

Daily Melatonin Injections Affect the Expression of Circadian

Rhythmicity in Djungarian Hamsters Kept under a Long-

Day Photoperiod

Puchalski, W.; Lynch, G.R.

Hypophyseal Actions of Pulsatile Gonadotropin-Releasing

Hormone in the Ewe: Development and Application of a

New Experimental Model

Kaynard, A.H.; Karsch, F.J

Importance of Pituitary and Neural Actions of Estradiol in

Induction of the Luteinizing Hormone Surge in the Ewe

Kaynard, A.H.; Malpaux, B.; Robinson, J.E.; Wayne, N.L.;

Karsch, F.J.

Lack of Acute J-Amphetamine Effects on Thyrotropin Re

lease

Little, K.Y.; Garbutt, J.C.; Mayo, J.P.; Mason, G

Twenty-Four-Hour Patterns of Pineal Melatonin and Pituitary and Plasma Prolactin in Male Rats under 'Natural' and Artificial Lighting Conditions

Laakso, M.-L.; Porkka-Heiskanen, T.; Alila, A.; Peder, M.;

Johansson, $\mathrm{G}$

Differential Effects of Pituitary Stalk-Section on Posterior

Pituitary and Hypothalamic Contents of Prolactin-Releasing Factor, Oxytocin, Dopamine and Beta-Endorphin

Hyde, J.F.; Murai, I.; Ben-Jonathan, N

Changes in Tuberoinfundibular Dopaminergic Neuron Activ

ity during the Rat Estrous Cycle in Relation to the Prolac

tin Surge: Alteration by a Mammary Carcinogen

Pasqualini, C; Bojda, F.; Gaudoux, F.; Guibert, B.; Leviel,

V.; Teissier, E.; Rips, R.; Kerdelhue, B.

Announcement

No. 4

\section{Original Paper}

In vivo Dopaminergic Activity from Nucleus accumbens, Substantia nigra and Ventral Tegmental Area in the Freely Moving Rat: Basal Neurochemical Output and Prolactin Effect

Chen, J.-C; Ramirez, V.D

Opiate Receptor Ontogeny in the Rat Medial Preoptic Area Is

Androgen-Dependent

Hammer, R.P., Jr 


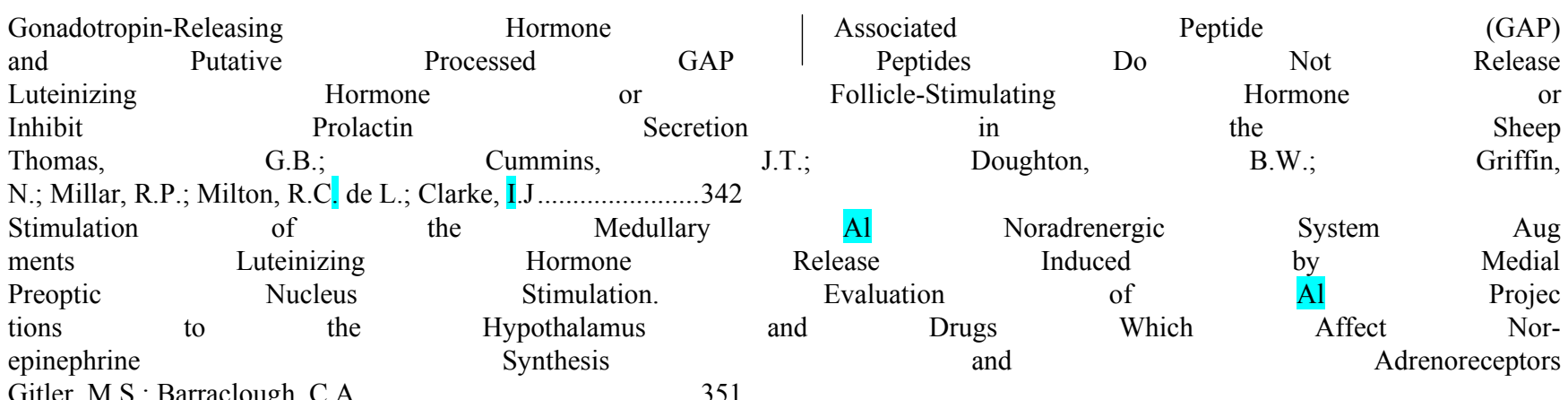

Gitler, M.S.; Barraclough, C.A …….................................... duced LH and FSH Release in Rat Anterior Pituitary Cells in Culture

Hubert, J.-F.; Thibault, L.; Turcotte, R.; Labrie, F. 360

Neuroendocrinological Function in Alzheimer's Disease

Franceschi, M.; Perego, L.; Ferini-Strambi, L.; Smirne, S.;

Canal, $\mathrm{N}$

Effects of Suprachiasmatic Nuclear Ablation and Melatonin

on Delayed Implantation in the Spotted Skunk

Berria, M.; DeSantis, M.; Mead, R.A ......................................371

Molecular Forms of Gonadotropin-Releasing Hormone Associated Peptide (GAP): Changes within the Rat Hypothalamus and Release from Hypothalamic Cells in vitro Ackland, J.F.; Nikolics, K.; Seeburg, P.H.; Jackson, I.M.D. 376

Lack of an Acute Modulatory Effect of Melatonin on Human Nocturnal Thyrotropin and Cortisol Secretion Strassman, R.J.; Peake, G.T.†; Quails, C.R.; Lisansky, E.J. 387

Alterations in Brain Opiate Receptor Mechanisms on Proestrous Afternoon

Berglund, LA.; Simpkins, J.W

Differential Neuroendocrine Responses to the 5-HT Agonist

m-Chlorophenylpiperazine in Fawn-Hooded Rats Relative

to Wistar and Sprague-Dawley Rats

Aulakh, C.S.; Wozniak, K.M.; Hill, J.L.; Devane, C.L.;

Tolliver, T.J.; Murphy, D.L

A Possible Role for Lipoxygenase and Epoxygenase Arachi-donate Metabolites in Prolactin Release from Pituitary Cells Judd, A.M.;

Spangelo, B.L.; Ehreth, J.T.; MacLeod, R.M. 407

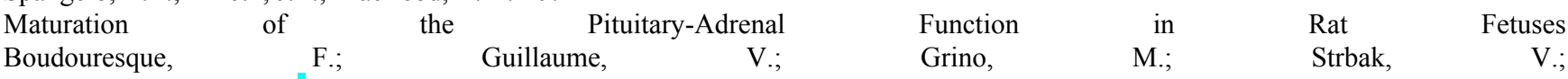

Chautard, T.; Conte-Devolx, B.; Oliver, C .............................4417

Human Fetal Adenohypophysis. Electron Microscopic and

Ultrastructural Immunocytochemical Analysis

Asa, S.L.; Kovacs, K.; Horvath, E.; Losinski, N.E.; Laszlo,

F.A.; Domokos, I.; Halliday, W.C

Pharmacodynamics of Gonadotropin-Releasing Hormone. I.

Effects of Gonadotropin-Releasing Hormone Pulse Con

tour on Pituitary Luteinizing Hormone Secretion in vivo in

Sheep

Handelsman, D.J.; Cummins, J.T.; Clarke, I.J

Long-Lasting Glucocorticoid Suppression of Opioid-Induced

Antinociception

Ratka, A; Sutanto, W.; De Kloet, E.R

Ionic Conductances in Cultured Pre-Infundibular Cells from the Hypothalamic Arcuate Region

Marani, E.; Corino, M.; Berg, R.J. van den; Rietfeld, W.J.;

Deenen, M.; Windhorst, W 
Original Paper

Rapid Effect of Testosterone on $\quad$ Striated Muscle $\quad$ Activity in Rats Sachs, B.D.; Leipheimer, R.E .............................................. 453

Effects of Catecholamine-Depleting Medullary Knife Cuts on

Corticotropin-Releasing Factor and Vasopressin Immunoreactivity in the Hypothalamus of Normal and SteroidManipulated Rats

Sawchenko, P.E

Synaptic Interconnections among Growth Hormone-Releasing

Hormone (GHRH)-Containing Neurons in the Arcuate

Nucleus of the Rat Hypothalamus

Horváth, S.; Palkovits, M.

Alpha-1- and Alpha-2-Noradrenergic Receptors Modulate

Lordosis Behavior in Female Guinea Pigs

Vincent, P.A.; Feder, H.H.

Characterization and Distribution of Receptors for Gonado

tropin-Releasing Hormone in the Rat Hippocampus

Leblanc, P.; Crumeyrolle, M.; Latouche, J.; Jordan, D.;

Fillion, G; L'Heritier, A.; Kordon, C; Dussaillant, M.;

Rostene, W.; Haour, F.

Pituitary Gonadotropin-Releasing Hormone Binding Sites in Persistent Estrous Rats Köves, K.; Kerdelhue, B.; Molnár, J.; Csernus, V.; Halász, B. 489

Influence of Ethanol on Growth Hormone Secretion in Adult and Prepubertal Female Rats

Dees, W.L.; Skelley, C.W.; Rettori, V.; Kentroti, M.S.;

McCann, S.M

Fractional Reduction of Somatostatin Concentration Inter

acted with Rat Growth Hormone Releasing Hormone to

Titrate the Magnitude of Pulsatile Growth Hormone and

Prolactin Release in Perfusion

Stachura, M.E.; Tyler, J.M.; Farmer, P.K

Patch-Clamp Study of the Ionic Currents Underlying Action Potentials in Cultured Frog Pituitary Melanotrophs Louiset, E.; Cazin, L;

Lamacz, M.;Tonon, M.-C; Vaudry, H. 507

Glutamic Acid Decarboxylase- and $\gamma$-Aminobutyric Acid-Like

Immunoreactivities in Corticotropin-Releasing Factor-

Containing Parvocellular Neurons of the Hypothalamic

Paraventricular Nucleus

Meister, B.; Hökfelt, T.; Geffard, M.; Oertel, W

Histaminergic Regulation of Prolactin Secretion: Involvement

of Serotoninergic Neurons

Knigge, U.; Sleimann, I.; Matzen, S.; Warberg, J

Ontogenesis of the Three Parts of the Fetal Rat Adenohypo

physis. A Detailed Immunohistochemical Analysis

Nemeskéri, Á,; Sétáló, G.; Halász, B

Gonadotropin-Releasing Hormone-Stimulated Phosphoinosi-

tide Hydrolysis in the Anterior Pituitary. Modulation by

Protein Kinase $\mathrm{C}$ but not by Cyclic Nucleotides

Sortino, M.A.; Evans, W.S.; Speciale, C; Thorner, M.O.;

Scapagnini, U.; MacLeod, R.M.; Canonico, P.L

Studies of the Regulation of the Hypothalamic-Pituitary-Adrenal Axis in Sheep with Hypothalamic-Pituitary Disconnection. I. Effect of an Audiovisual Stimulus and Insulin-Induced Hypoglycemia

Engler, D.; Pham, T.; Fullerton, M.J.; Funder, J.W.;

Clarke, I.J 
Quantitative Assessment of Early and Discontinuous Estradiol-Induced Effects on Ventromedial Hypothalamic and Preoptic Area Proteins in Female Rat Brain Jones, K.J.; McEwen, B.S.; Pfaff, D.W .561

Activation of Anterior Pituitary

Formation of Estrogen-Induced

Folliculo-Stellate Cells

Prolactin-Secreting

the

Schechter, J.; Ahmad, N.; Weiner, R .569

No. 6

\section{Original Paper}

Melatonin Receptors in Discrete Brain Areas of the Male Rat. Impact of Aging and on Density on Circadian Rhyth-

micity

Laudon, M.; Nir, I.; Zisapel, N.

Declining Plasma Progesterone Levels Eliminate Endogenous

Opioid Peptide Suppression of LH Pulse Frequency on

Day 22 of Gestation in the Rat

Devorshak-Harvey, E.; Bona-Gallo, A.; Gallo, R.V. ... 584 Catecholaminergic Innervation of Luteinizing Hormone-Releasing Hormone and Glutamic Acid Decarboxylase Im-

munopositive Neurons in the Rat Medial Preoptic Area.

An Electron-Microscopic Double Immunostaining and Degeneration Study

Leranth, C; MacLusky, N.J.; Shanabrough, M.; Naftolin, F. 591 Post-Translational Processing of Pro-Opiomelanocortin in the Brattleboro (di/di) Rat Pituitary

Canny, B.J.; Smith, A.I.; Clements, J.A.; Funder, J.W. . 603 Loperamide, an Opiate Analog, Differently Modifies the Adrenocorticotropin Responses to Corticotropin-Releasing

Hormone and Lysine Vasopressin in Patients with Addi-

son's Disease

Bochicchio, D.; Ambrosi, B.; Faglia, G

Infusion of prepro-VIP Derived Peptides in Man: Effect on

Secretion of Prolactin

Yiangou, A.; Gill, J.S.; Chrysanthou, B.J.; Burrin, J.;

Bloom, S.R

Neurohypophyseal Aging: Differential Changes in Oxytocin

and Vasopressin Release, Studied in Fischer 344 and

Sprague-Dawley Rats

Zbuzek, V.; Fuchs, A.-R.; Zbuzek, V.K.; Wu, W 
Modulation of Growth Hormone-Releasing Factor Stimulated

Growth Hormone Secretion by Plasma Glucose and Free

Fatty Acid Concentrations in Sheep

Sartin, J.L.; Bartol, F.F.; Kemppainen, R.J.; Dieberg, G.;

Buxton, D.; Soyoola, E.

Effects of Dopaminergic Blockade on the Sleep-Associated

Changes of Luteinizing Hormone Pulsatility in Early Fol-

licular Phase Women

Rossmanith, W.G.; Mortola, J.F.; Yen, S.S.C

Modulation of Plasma Glucose Levels by Thyrotropin-Releas-ing Hormone Administered Intracerebroventricularly in the Rat Marubashi, S.; Kunii, Y.; Tominaga, M.; Sasaki, H. ... 640

Neonatal Treatment with Monosodium Glutamate Increases Plasma Corticosterone in the Rat

Dolnikoff, M.S.; Kater, C.E.; Egami, M.; Andrada, I.S. de;

Marmo, M.R.

Comparison of Adrenocorticotropin Control in Brattleboro, Long-Evans, and Wistar Rats. Measurement of Corticotropin-Releasing Factor, Arginine Vasopressin, and Oxytocin in Hypophysial Portal Blood

Tannahill, L.A.; Dow, R.C.; Fairhall, K.M.; Robinson,

I.C.A.F.; Fink, G

Effect of the Opioid Kappa-Receptor Agonist U50488H on the Secretion of Arginine Vasopressin. Study on the Mechanism of U50488H-

Induced Diuresis Oiso, Y.; Iwasaki, Y.; Kondo, K..; Takatsuki, K.; Tomita, A. 658

Mass and Activity of Tyrosine Hydroxylase in Tuberoinfundi-

bular Dopaminergic Neurons of the Aged Brain. Control

by Prolactin and Ovarian Hormones

Gonzalez, H.A.; Kedzierski, W.; Porter, J.C, .........................663

Naloxone Potentiation of Effects of Cholecystokinin and Lith

ium Chloride on Oxytocin Secretion, Gastric Motility and

Feeding

Flanagan, L.M.; Verbalis, J.G.; Strieker, E.M.

\section{Rapid Communication}

Corticotropin-Releasing Factor: Evidence for a Neurotrans-

mitter Role in the Locus ceruleus during Hemodynamic

Stress

Valentino, R.J.; Wehby, R.G.

Author Index

Subject Index 